\title{
MICROBIOLOGICAL AND ENERGETIC ASSESSMENT OF THE EFFECTS OF THE BIODRYING OF FUEL PRODUCED FROM WASTE
}

\author{
MIKROBIOLOGICZNA I ENERGETYCZNA OCENA EFEKTÓW BIOSUSZENIA \\ PALIWA WYTWARZANEGO Z ODPADÓW KOMUNALNYCH
}

\begin{abstract}
Biological drying (biodrying) is one of the methods of biological processing of waste, used mainly as part of the mechanical biological treatment of mixed municipal waste. Biological drying uses the heat released during the decomposition of organic matter to reduce the amount of water in dried waste. The aim of the analyses was to provide a microbiological and energetic (fuel) assessment of the process of biodrying of alternative fuel (RDF) obtained by mechanical sorting of mixed municipal waste. The resulting alternative fuel (obtained with just sorting) is characterised by varied moisture content and the presence of diverse groups of microorganisms. The analyses were intended to assess 3 alternative methods of biodrying of alternative fuel in order to produce a stable end product for utility power generation and the cement industry. The analyses were performed using special bioreactors equipped with custom (innovative) fluidised bed, aeration system (air flow rate $500 \mathrm{~m}^{3} \cdot \mathrm{h}^{-1}$ ), effluents drain systems, post-process air offtake and 4 temperature sensors. The assessment of the impact of the employed bed aeration methods on the quality of the alternative fuel was performed in 3 repetitions with the same external parameters. The obtained results show that after 8 days of biodrying, in the most favourable option, the moisture content in the fuel was reduced to the level of $18.7 \%$, i.e. by $39 \%$, the resulting fuel was microbiologically stable and the calorific value of the fuel was increased on average by $3.2 \mathrm{MJ} \cdot \mathrm{kg}^{-1}$.
\end{abstract}

Keywords: waste, alternative fuel, microorganisms, biodrying

\section{Introduction}

The production of alternative fuels is a well known and often used method of processing mixed municipal solid waste (MSW). The fuels (SRF) are produced from waste by means of mechanical sorting with separators (e.g. drum, optical, ballistic, pneumatic, magnetic) and shredders $[1,2]$. Different technological processes are normally adopted to produce SRF. The methods based on biodrying the mixed municipal waste and separating combustible waste fractions are increasingly popular in Europe. The final fuel

\footnotetext{
${ }^{1}$ Department of Technical Infrastructure and Eco-power Engineering, Institute of Agricultural Engineering and Computer Science, University of Agriculture in Krakow, ul. Balicka 116 b/311, 30-149 Kraków, Poland, phone +48 1266246 60, email: mateusz.malinowski@urk.edu.pl

${ }^{2}$ Department of Microbiology, University of Agriculture in Krakow, al. A. Mickiewicza 24/28, 30-059 Kraków, Poland, phone +48 1266240 96, email: katarzyna.wolny@urk.edu.pl

*Corresponding author: mateusz.malinowski@urk.edu.pl
} 
is usually used for energy production in utility power generation plants or cement plants in bulk (loose) or agglomerated form (pellets). The fuel obtained from mixed municipal solid waste should conform to appropriate quality standards in order to ensure environment protection [3]. The key properties of alternative fuel, deciding on its suitability for incineration in cement kilns are: calorific value $\left(>14 \mathrm{MJ} \cdot \mathrm{kg}^{-1}\right)$, moisture content $(<15 \%)$, content of chlorine $(<0.8 \%)$, sulphur $(<2.5 \%)$ and ash $(<15 \%)$, PCB content $\left(<50 \mathrm{mg} \cdot \mathrm{kg}^{-1}\right)$, heavy metals content $\left(<2500 \mathrm{mg} \cdot \mathrm{kg}^{-1}\right)$ [4]. Due to the heterogeneous morphological composition of municipal waste (depending on multiple factors), compliance with the aforementioned standards may be difficult. In the case of mixed municipal waste the separation of the so-called combustible fraction in itself does not yet predestine it for use in the power industry [5]. The key factor influencing the quality of refuse-derived fuel is its moisture content and the content of organic substance $[2,5,6]$, fostering the growth of microorganisms. It is crucial to seek effective methods of fuel drying that are low in cost and material demand, in order to achieve the optimum calorific value of the end product together with the reduction of the process duration and electricity consumption. Biological drying, based on the natural increase in temperature (self-heating) of the stored fuel can be employed to that effect. There are even known cases of self-combustion of alternative fuel during storage [7, 8]. Hogland and Marques [9] described self-combustions incidents for fuel stored in piles even after 6 months from the date of fuel production. The increase in the temperature is a result of the decomposition of organic matter by microorganisms present in the fuel, due to the optimal growth conditions, i.e. large volume of free spaces, significant degree of material refinement and the contents of organic matter from mixed municipal solid waste.

Biological drying is an autothermic (self-heating) process, using heat generated by organic matter decomposition for drying. The self-heating of waste in the result of the decomposition of the biodegradable fraction of the organic matters. Biodrying leads to the decrease in moisture content with simultaneous preservation (or increase) of the calorific value, resulting in the production of a stable, solid fuel [10] with reduced moisture content, characterised by the termination of biological degradation [11-14]. Biodrying is usually viewed as the process of biological processing of mixed municipal solid waste before sorting in mechanical-biological processing systems [11, 12, 15-18], however it is rarely seen as the process of increasing the quality (calorific value and microbiological stability) of the final fuel. It is not to be forgotten that mixed municipal solid waste is a mixture of many types of waste, including organic (green, cooking, paper, cardboard, etc.), part of which, independently of the precision of the sorting process travels to the alternative fuel and lowers its energetic properties. This means that the materials used to produce the RDF and the alternative fuel itself cannot pose a microbiological threat to the persons employed in the production process. This is the reason why the analysis of the number and species composition of the microorganisms found in the SRF is very interesting, for informative purposes.

Microorganisms can influence the properties of alternative fuel but also be a source of threat for persons employed in the production process. Analyses of the microbiological contamination of air, water and soil in municipal objects (sewage treatment plants, landfills, composting plants) and in their immediate surroundings are performed [19-24]. Studies concerning the number of microorganisms in alternative fuel (RDF) produced from municipal solid waste are still not numerous [25, 26]. Pathogenic microorganisms are often found in abundance in municipal waste storage locations, resulting in a health 
risk for persons employed in their segregation and treatment. Sakka et al. [26] studied the species composition of the population of microorganisms found in alternative fuel. Using molecular biology methods, based on the analysis of the sequence of 16S rRNA, they found: Clostridium spp., Bacillus spp., Paenibacillus spp., Thermoanaerobacterium spp., Pseudoxanthomonas spp., Sphingobacterium spp. as well as Streptomyces spp. actinobacteria.

The main purpose of this study was to determine the changes in the technological properties of alternative fuel (produced with sorting) by subjecting it to the biological drying process using 3 different aeration methods, with particular attention to the energetic properties and the number and species composition of microorganisms found in the fuel (RDF). Furthermore, a bioreactor with an innovative bed was used for the biodrying process in the study. The innovativeness of the solution should yield better final parameters of the fuel (improved technological properties), such as moisture content and calorific value and should enable the sanitisation of processed waste.

\section{Materials and methods}

\section{Analysis material and location}

The material for analysis was alternative fuel produced from mixed municipal solid waste collected in the area of Krakow. Samples for analysis were collected in the MIKI Recykling Sp. z o.o. company in Krakow. The company owns a mechanical-biological municipal waste processing unit as well as an alternative fuel production system. The produced alternative fuel is usually stored in the form of aerated prisms with rectangular base ( $6 \times 10$ metres) and the height of up to 3 metres, from which the samples for analysis were collected. Figure 1 is a schematic representation of the technological process. Table 1 contains a list of the most important parameters of the fuel made from municipal waste in the company - analysis material.

Table 1

Morphological and chemical composition of the alternative fuel after biodrying

\begin{tabular}{|c|c|c|c|c|c|c|c|}
\hline No. & \multicolumn{2}{|c|}{ Parameter } & Unit & Mean & \pm SD & Research standard & Analytical unit \\
\hline 100 & \multirow{10}{*}{ 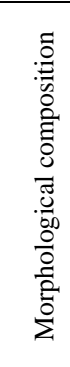 } & Plastics & {$[\%]$} & 65.6 & \pm 5.1 & \multirow{10}{*}{$\begin{array}{c}\text { PN Z 15006:1993 } \\
{[27]}\end{array}$} & \multirow{10}{*}{$\begin{array}{l}\text { Manual analysis } \\
\text { using the WLC } \\
6 / \mathrm{F} 1 / \mathrm{K} \text { precision } \\
\text { balance }\end{array}$} \\
\hline \multirow{9}{*}{1.} & & Organic waste & {$[\%]$} & 3.6 & \pm 1.0 & & \\
\hline & & Wood & {$[\%]$} & 3.9 & \pm 0.7 & & \\
\hline & & Paper & [\%] & 11.3 & \pm 2.7 & & \\
\hline & & Textiles & [\%] & 2.9 & \pm 1.6 & & \\
\hline & & Glass & {$[\%]$} & 0.2 & \pm 0.1 & & \\
\hline & & \begin{tabular}{|c|} 
Metal \\
\end{tabular} & {$[\%]$} & 0.3 & \pm 0.2 & & \\
\hline & & Composite waste & {$[\%]$} & 3.5 & \pm 0.9 & & \\
\hline & & Inert waste & {$[\%]$} & 2.2 & \pm 2.3 & & \\
\hline & & $\begin{array}{c}\text { Undersize } \\
\text { fraction }<2 \mathrm{~mm}\end{array}$ & {$[\%]$} & 6.6 & \pm 2.8 & & \\
\hline 2. & \multicolumn{2}{|c|}{ Total carbon content $(\mathrm{C})$} & {$[\%]$} & 46.53 & \pm 0.15 & \multirow{3}{*}{$\begin{array}{c}\text { PN-EN 15407:2011 } \\
{[28]}\end{array}$} & ELTRA CHS 580 \\
\hline 3. & \multicolumn{2}{|c|}{ Nitrogen content $(\mathrm{N})$} & [\%] & 1.25 & \pm 0.15 & & ELTRA N 580 \\
\hline 4. & \multicolumn{2}{|c|}{ Hydrogen content $(\mathrm{H})$} & {$[\%]$} & 6.32 & \pm 0.65 & & ELTRA CHS 580 \\
\hline 5. & \multicolumn{2}{|c|}{ Sulphur content (S) } & {$[\%]$} & 0.09 & \pm 0.02 & $\begin{array}{c}\text { PN-G-04584:2001 } \\
{[29]}\end{array}$ & ELTRA CHS 580 \\
\hline
\end{tabular}




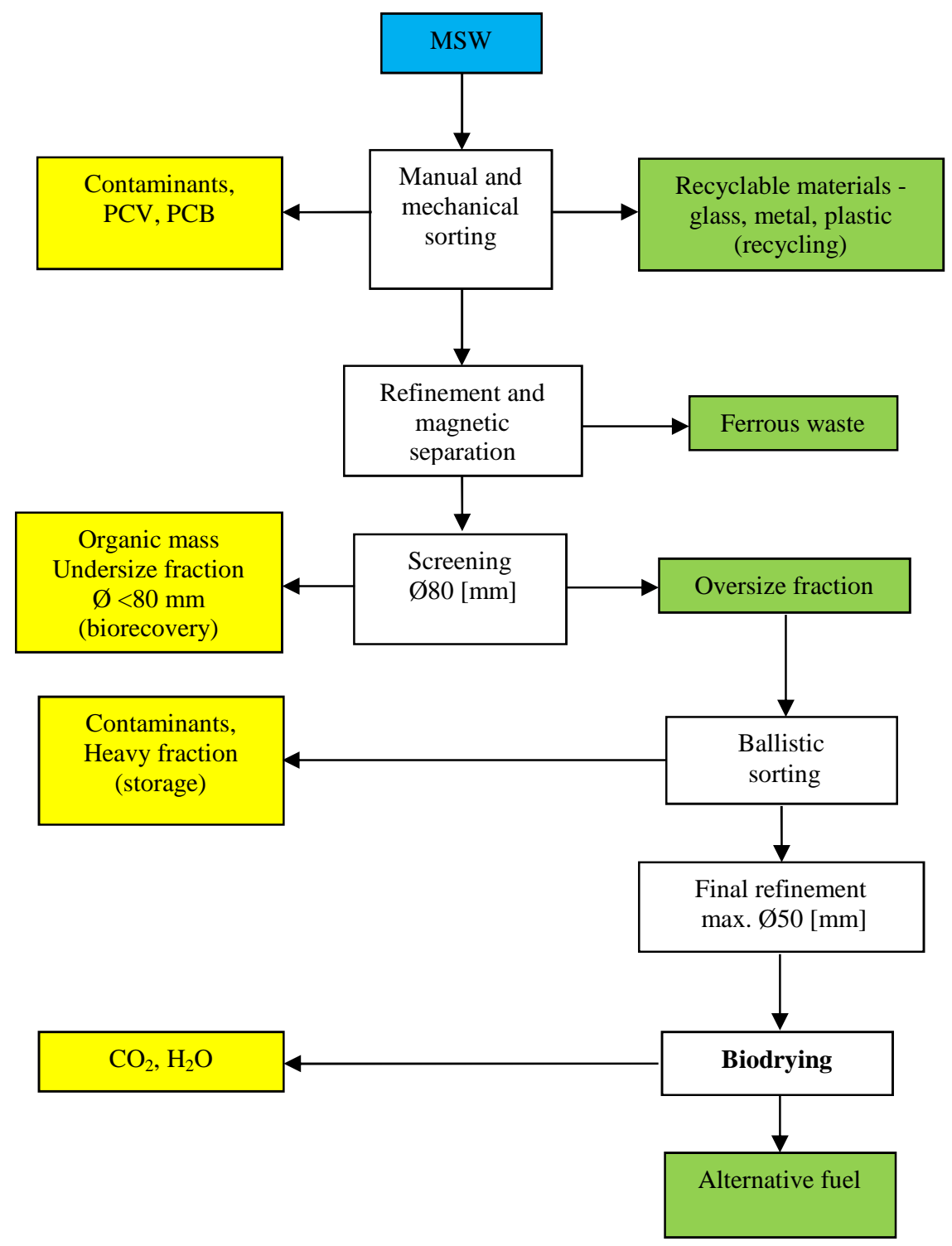

Fig. 1. Schematic technological diagram

The process of the biological drying of waste was implemented in bioreactors with the total capacity of $36 \mathrm{~m}^{3}$ and working capacity of $31.5 \mathrm{~m}^{3}$ (2.1 m width, $6.5 \mathrm{~m}$ length and $2.3 \mathrm{~m}$ height). The remaining volume of the bioreactor is the area under the fluidised bed (Fig. 2), used for the introduction of air and collection of effluents. The bioreactors were based on hook containers, which allow their direct loading onto a special vehicle (hooklift truck) and measuring mass loss in the consecutive days of the cycle (on a legalised weighbridge). The bioreactors were equipped with an inspection opening used 
to collect samples for laboratory testing. Humid post-process air was transported to the biological filter. Aeration of the bed in each of the bioreactors was provided using a fan with the nominal power rating of $0.55 \mathrm{~kW}$. The analysis was provided to a technical scale. Each of the bioreactors had a thermal insulation layer (polystyrene foam) with the thickness of $10 \mathrm{~cm}$.

Typical bioreactors for waste biodrying use beds made of a plate with drilled holes of different diameters. The innovativeness of the solution used in the study was that to use six injectors $(0.05 \mathrm{~m}$ width, $6.5 \mathrm{~m}$ length and $0.04 \mathrm{~m}$ height) laid along the whole bed and connected with a flat bar in the bed (Fig. 2). Each of the injectors had half-circle openings $(r=0.025 \mathrm{~m})$ at both sides. The total area of the openings in all 6 injectors was equal to ca. $7 \%$ of the total area of the bed [30]. This solution provides better air distribution in the dried material and reduces the possibility of clogging the openings with waste.
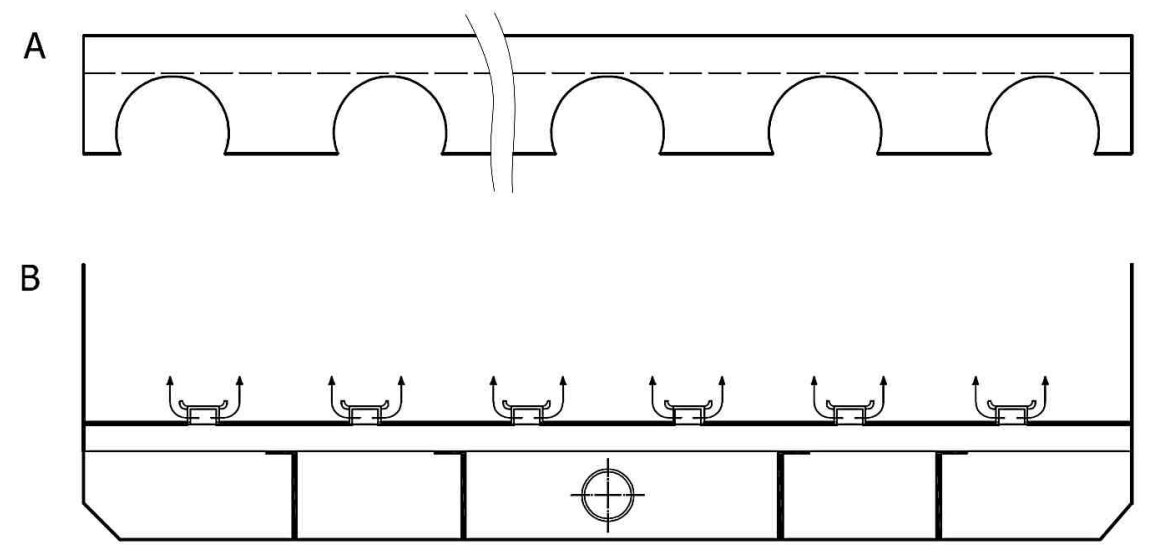

Fig. 2. Fluidised bed of the bioreactor - diagram (A - side view, B - front view) [30]

\section{Process parameters}

The biodrying process was implemented simultaneously in 3 bioreactors. Each of the bioreactors had different aeration and internal temperature regulation parameters. Different methods were employed in order to assess and select the optimal method. Process temperature was monitored automatically using thee two-metre PT 100 probes inserted from the top (through the roof the of the bioreactor) in 3 different points of the bioreactor, i.e. in the central part, 2 metres from the air inlet and 2 metres from the bioreactor wall with air outlet. Furthermore, the ambient temperature and outlet air temperature were measured. The process control program also recorded airflow data. The mass of the waste processed in bioreactors was measured during the course of the process using a legalised weighbridge.

In the first research variant (K4 bioreactor), upon reaching the temperature of $65^{\circ} \mathrm{C}$, the aeration control program (ARSoft) switched on the fan which provided fresh air for the whole time (fan rate: $1000 \mathrm{~m}^{3} \cdot \mathrm{h}^{-1}$ ). In the second variant (K5 bioreactor), upon reaching the dried mass temperature of $65^{\circ} \mathrm{C}$, the aeration control program switched on the fan which provided fresh air until the temperature decreased by $1^{\circ} \mathrm{C}$. The program started the fan again after reaching the charge temperature of $65^{\circ} \mathrm{C}$. In the third variant 
(K6 bioreactor), the mass was not aerated in order to determine the actual effect of process temperature on microorganisms found in the alternative fuel. In all three cases, the process was stopped after 8 days. Velis et al. [31] report that the optimal time for biological drying is from 7 to 15 days. The average daily outside air temperature was $15.5^{\circ} \mathrm{C}$.

Various optimal temperature ranges have been reported in the literature, namely $55-70^{\circ} \mathrm{C}$ [32]; 50-60 ${ }^{\circ} \mathrm{C}$ [33] and ca. $65^{\circ} \mathrm{C}$ [34]. The temperature of $65^{\circ} \mathrm{C}$ was selected in order to destroy the pathogenic microorganisms in the drying process in order to prevent repeated self-heating of the dried mass. These microorganisms die in the temperature of $60-65^{\circ} \mathrm{C}$.

\section{Sample collection and microbiological analysis}

Three 100-gram samples (treated as repetitions) were collected from the depth of $1 \mathrm{~m}$ into the alternative fuel storage pile on 30 August 2014, placed in sterile containers and immediately transported into the laboratory of the Microbiology Department of the University of Agriculture in Krakow for microorganisms isolation. The isolation was provided using the Koch's serial dilution method on a number of microbiological growth media. The following types of microorganisms were found: general bacteria, vegetative bacteria and bacterial endospores (bacteriological agar, BTL), mould fungi (glucose and potato agar PDA, BTL), actinobacteria (Pochon agar, BTL). The values of the titres of microorganisms involved in nitrogen processing were determined: nitrifiers (Winogradski growth medium [19, 20]), denitrifiers (Giltay growth medium [19, 20]), as well as the number of units in the colony of Azotobacter spp. (Ashby agar [19, 20]) and for ammonification microorganisms (Rougieux medium [19, 20]). The presence of the potentially pathogenic bacteria was also analysed: Staphylococcus spp. (Chapman agar, BTL), Escherichia coli (at $37^{\circ} \mathrm{C}$ ) and Escherichia coli (at $44^{\circ} \mathrm{C}$ thermotolerant strains; Endo agar, TBX agar, BTL), Salmonella spp. and Shigella spp. (SS agar, BTL), Enterococcus faecalis (Slanetz Bartley medium, BTL), Clostridium perfringens (Wilson-Blair medium, BTL). The $\mathrm{pH}$ of the alternative fuel samples was also measured alongside the air temperature in the RDF storage hall. The number of colony forming units (CFU) of microorganisms was determined using the inoculation of dilutions, calculating the result for one gram of the fuel or by determining the titres for the microorganisms involved in the nitrification and denitrification processes.

Samples were collected twice, the first series of tests (30.08.2014) intended to determine the number and species composition of microorganisms found in the RDF during the pile storage period. The second series of tests (08.09.2014) was completed after the biodrying process of the fuel from the previously tested pile. Three 100-gram samples were collected from each of the piles (K4, K5, K6) for microbiological analysis. Further procedure was identical to the first series of tests. Samples were labelled as follows: 1, 2, 3 - fuel samples collected from the pile before the biodrying process; samples collected after the biodrying process: K4.1, K4.2, K4.3, K5.1, K5.2, K5.3, K6.1, K6.2, K6.3.

The statistical analysis was performed using the Statistica v. 10 software (StatSoft). Mean number of microorganisms was determined for the tested samples. A variance analysis (ANOVA) was performed in order to verify the significance of spatial differences in the number of microorganisms for selected groups. 


\section{Fuel (energetic) properties analysis}

Alternative fuel samples for analysis were collected from the pile before biodrying (30 samples) on 30 August 2014 and after the process, from the bioreactors, using the inspection opening on 8 September 2014 (30 samples from each of the bioreactors). Samples for testing were collected according to the methodology recommended by [35] the European Committee for Standardization, 2006. Characterization of Waste - Sampling of Waste Materials - Framework for the Preparation and Application of a Sampling Plan (EN 2006, 14899). Studies performed at the laboratory of the Production and Power Engineering Faculty of the University of Agriculture in Krakow determined the bulk density of the fuel as well as the moisture content which were determined by weight loss mass of dried waste at $105^{\circ} \mathrm{C}$ [36]. The weight of each of the pre-drying waste samples was about $1000 \mathrm{~g}$. The samples were also analysed for fuel properties, as a basis for the assessment of viability of the waste for energy generation, to determine:

- $\quad$ heat of combustion, using the calorimeter method, according to PN-ISO 1928 [37] and PN-Z 15008-04:1993 [38]. The determination was made using a weighted sample of $(1.1 \pm 0.1) \mathrm{g}$ placed in a bomb calorimeter (KL-12 calorimeter) in the form of a pressed pellet. The combustion of the sample was achieved using a $0.1 \mathrm{~mm}$ Kanthal wire pressed into the pellet. The calorific value was calculated using the computer software controlling the operation of the calorimeter;

- calorific value according to PN-Z 15008-04:1993 - Municipal solid waste - Tests for fuel properties - Determination of the heat of combustion and calculation of the calorific value [38];

- $\quad$ ash content according to PN-EN 18122:2016-01 [39] by incineration of the sample in a chamber furnace at $815^{\circ} \mathrm{C}$.

The statistical analysis was performed using the Statistica v. 10 software (StatSoft). Variance analysis (ANOVA) was performed to check the statistical significance of the differences in the properties of the fuel dried in different bioreactors.

\section{Results and discussion}

Based on the microbiological analyses, a large variety of microorganisms can be found in the alternative fuel at different stages of biodrying. The changes in the number and species composition of the microorganisms population before and after the process should be noted. The largest mean numbers of microorganisms were found in samples collected from the pile (Table 2). Furthermore, all microorganism groups apart from Shigella spp. were found, including pathogenic bacteria (Staphylococcus spp., E. coli, Salmonella spp., E. faecalis, $C$. perfringens). The pile was located in a well-ventilated hall, the temperature inside the hall during the time of the study was ca. $23-26^{\circ} \mathrm{C}$. The mean moisture content in the pile was $30.8 \pm 4.3 \%$. These conditions were favourable to the growth of vegetative bacteria, fungi and actinobacteria. A large number of microorganisms involved in nitrogen processing (Azotobacter spp. and ammonifiers) were also found in the pile, as well as large titre values for nitrification and denitrification bacteria. The alternative fuel at this stage is abundant with organic matter - a source of easily absorbed nutrients for the microorganisms.

The presence of actinobacteria and Azotobacter bacteria was not found in bioreactors K4 and K5 after the completion of the process. Furthermore, pathogenic microorganisms, i.e. E. coli, Salmonella spp. and Shigella spp. were not found. This is very important, from 
the sanitary perspective, and leads to believe that the biodrying process may result in a satisfactory sanitation of the alternative fuel. In the biodried samples, endospores of C. perfringens (K4, K5), E. faecalis (K5) as well as Staphylococcus (K4, K5) bacteria were found, it is to be noted, however, that the number of staphylococci and faecal streptococci was greatly reduced. Precisely specified biodrying parameters had very visible impact on the number and species composition of microorganisms collected from K4 and K5 bioreactors. The increase of endospore bacteria and decrease of vegetative bacteria was very clear. This may be caused by the presence of unfavourable conditions in the biodrying process (high temperature, reduced moisture) and limited availability of nutrients. The decrease in the mean number of mould fungi was found, possibly attributed to increased $\mathrm{pH}$.

Table 2

Mean numbers of microorganisms $\left(\mathrm{CFU} \cdot \mathrm{g}^{-1} \mathrm{RDF}\right)$, mean titre values for nitrification and denitrification bacteria and $\mathrm{pH}$ of tested $\mathrm{RDF}$ samples

\begin{tabular}{|c|c|c|c|c|}
\hline \multirow{2}{*}{ Microorganism } & \multirow{2}{*}{$\begin{array}{c}\text { Samples before biodrying } \\
\text { Pile }\end{array}$} & \multicolumn{3}{|c|}{ Samples after biodrying } \\
\hline & & K4 & K5 & K6 \\
\hline Vegetative bacteria & $3,925,000$ & 221,567 & 650,933 & 640,033 \\
\hline Bacterial endospores & 9,083 & $30,532,000$ & 239,933 & 452,667 \\
\hline Mould fungi & 81,985 & 1,477 & 563 & 31,592 \\
\hline Actinobacteria & 168 & 0 & 0 & 183 \\
\hline Staphylococcus spp. & 2,791 & 46 & 39 & 74 \\
\hline E. coli $\left(37^{\circ} \mathrm{C}\right)$ & 29,350 & 0 & 0 & 397 \\
\hline E. coli $\left(44^{\circ} \mathrm{C}\right)$ & 45,667 & 0 & 0 & 370 \\
\hline Salmonella spp. & 5,320 & 0 & 0 & 971 \\
\hline Shigella spp. & 0 & 0 & 0 & 0 \\
\hline E. faecalis & 57 & 0 & 9 & 34 \\
\hline C. perfringens & 11 & 5 & 11 & 11 \\
\hline Azotobacter spp. & 844 & 0 & 0 & 0 \\
\hline Ammonifiers & 323,278 & 4,516 & 441,661 & 158,958 \\
\hline Nitrifiers & $10^{-5}$ & $10^{-3}$ & $10^{-2}$ & $10^{-3}$ \\
\hline Denitrifiers & $10^{-5}$ & $10^{-3}$ & $10^{-2}$ & $10^{-3}$ \\
\hline $\mathrm{pH}$ & 7.55 & 8.16 & 8.23 & 7.93 \\
\hline
\end{tabular}

The results of the analysis of the samples from the K6 bioreactor, without aeration, need to be discussed separately. The moisture content in the K6 bioreactor during the process increased by approximately $40 \%$. The temperature of $65^{\circ} \mathrm{C}$ was achieved after 47 hours and continued to increase, however the water condensing on the walls of the bioreactor was not drained and accumulated in the fuel. The samples collected from the K6 bioreactor were soaked in water, very different from the dry samples from the K4 and K5 bioreactors. After the microbiological analysis of the samples from the K6 bioreactor, several differences were found, in comparison to the other two bioreactors. A large mean number of mould fungi and actinobacteria was found, probably due to high moisture content. The presence of pathogenic microorganisms (Staphylococcus spp., E. coli, Salmonella spp., E. faecalis, C. perfringens) is a cause for concern.

Based on the collected data, it can be stated that the lack of aeration during the biodrying process resulted not only in the decreased calorific value of the fuel but also prevented its sanitation. Microorganisms involved in nitrogen circulation (ammonifiers, nitrifiers, denitrifiers) were found in all bioreactors. The mean number of ammonifiers was not greatly changed by biodrying. The mean titre values for nitrification and 
denitrification bacteria decreased from $10^{-5}$ to $10^{-2}$ (K5) and $10^{-3}$ (K4, K6). During the aerobic processing of waste, simultaneous nitrification and denitrification, leading to the decrease of ammonium nitrogen [40, 41] produced during the mineralisation of substances containing organic nitrogen, i.e. proteins, amino acids and urea in the process of ammonification can be observed [13]. During the biological processing of organic matter, the microorganisms involved in the waste treatment process use part of the ammonium acid for biomass synthesis, the remained is released into the atmosphere [42], which is the cause of multiple problems, i.e. odours, discharge of toxic compounds into the ecosystem and eutrophication of water reservoirs [43].

Based on the statistical analysis of the results, it was found that the differences of the number of microorganisms between the sampling locations are statistically significant in the case of Staphylococcus spp., Salmonella spp. and ammonifiers (Table 3).

Figure 3 shows the change in temperature during the biodrying process in each of the analysed bioreactors. The average temperature of the fuel loaded into the bioreactor was $24.5^{\circ} \mathrm{C}$. In the first 12 hours, the temperature in each of the bioreactors decreased by $3-4^{\circ} \mathrm{C}$, as a result of the decrease of the temperature of infeed air at night. In the 30th hour of the process, a "manual", 20-minute aeration of the bed was performed in order to stimulate the microorganisms in the waste. The target temperature of $65^{\circ} \mathrm{C}$ was achieved in the 49th hour of the process, at the latest.

Table 3

Variance analysis results for the spatial differences in the number of microorganisms

\begin{tabular}{|c|c|c|c|}
\hline Microorganism & F factor value (collection point) & Microorganism & F factor value (collection point) \\
\hline Vegetative bacteria & 1.96 & Salmonella spp. & $107.87^{*}$ \\
\hline Bacterial endospores & 1.92 & E. faecalis & 1.16 \\
\hline Mould fungi & 3.57 & C. perfringens & 0.32 \\
\hline Actinobacteria & 2.63 & Azotobacter spp. & 1.28 \\
\hline Staphylococcus spp. & $11.49^{*}$ & Ammonifiers & $5.25^{*}$ \\
\hline E. coli $\left(37^{\circ} \mathrm{C}\right)$ & 1.72 & Nitrifiers & 3.44 \\
\hline E. coli $\left(44^{\circ} \mathrm{C}\right)$ & 3.26 & Denitrifiers & 3.44 \\
\hline
\end{tabular}

* values are significant with $p<0.05$

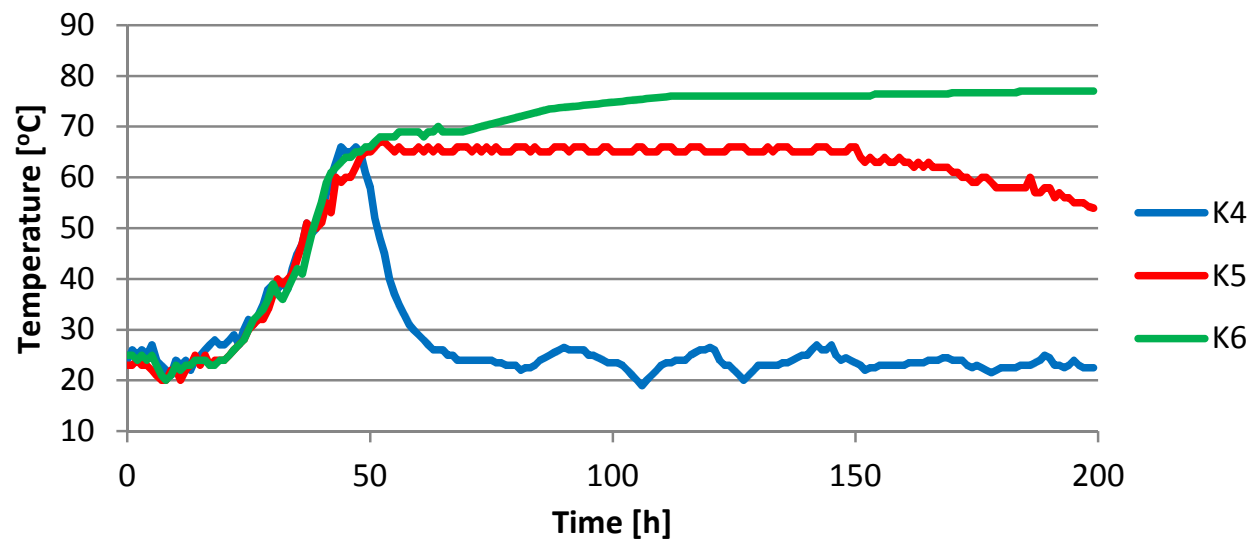

Fig. 3. Changes in alternative fuel temperature in the $\mathrm{K} 4, \mathrm{~K} 5$ and $\mathrm{K} 6$ bioreactors 
In the $\mathrm{K} 4$ bioreactor, after reaching the temperature of $65^{\circ} \mathrm{C}$, and cooling down the bed with intensive aeration, the temperature changes due to the introduction of air of different temperature (day/night) were observed. The fan was switched on in the 44th hour of the process and was kept on for the further 158 hours. The total consumption of electric power was: $87 \mathrm{kWh}$. In the $\mathrm{K} 5$ bioreactor, the bed temperature of $64-65^{\circ} \mathrm{C}$ was maintained for 102 hours and then started to decrease. Between the 49th and the 151st hour of the process, the fan switched on 56 times (single aeration time - from 0.5 minute to as much as 2 hours). The fan at the K5 bioreactor only consumed $4.6 \mathrm{kWh}$ of power. In the K6 bioreactor, in which the fuel was not aerated, the temperature of the fuel increased gradually to the level of $76^{\circ} \mathrm{C}$. The total power consumption of the fan was $0.3 \mathrm{kWh}$ (manual aeration during the second day). Table 4 presents the results of the analyses of fuel (energetic) properties for the samples collected from the pile and each of the bioreactors after 8 days of processing.

Energetic properties of alternative fuel

Table 4

\begin{tabular}{|c|c|c|c|c|c|}
\hline \multirow{2}{*}{ Parameter } & \multirow{2}{*}{ Unit } & $\begin{array}{c}\text { Samples before } \\
\text { biodrying }\end{array}$ & \multicolumn{3}{|c|}{ Samples after biodrying } \\
\cline { 3 - 6 } & & Pile & K4 & K5 & K6 \\
\hline Moisture content & {$[\%]$} & $30.8 \pm 4.3$ & $18.7 \pm 1.9$ & $21.5 \pm 2.2$ & $38.5 \pm 2.1$ \\
\hline $\mathrm{pH}$ & - & $7.55 \pm 0.13$ & $8.16 \pm 0.01$ & $8.23 \pm 0.02$ & $7.93 \pm 0.02$ \\
\hline Heat incineration & {$\left[\mathrm{MJ} \cdot \mathrm{kg}^{-1}\right]$} & $22.4 \pm 0.6$ & $22.2 \pm 0.3$ & $22.6 \pm 0.4$ & $22.1 \pm 0.5$ \\
\hline Calorific value & {$\left[\mathrm{MJ} \cdot \mathrm{kg}^{-1}\right]$} & $13.1 \pm 1.8$ & $16.2 \pm 1.0$ & $15.8 \pm 0.7$ & $11.2 \pm 0.7$ \\
\hline Ash content & {$[\%$ d.m.] } & $9.1 \pm 1.1$ & $10.8 \pm 1.9$ & $9.1 \pm 1.6$ & $9.3 \pm 1.9$ \\
\hline
\end{tabular}

It was concluded that the differences between the fuel from the $\mathrm{K} 4$ and $\mathrm{K} 5$ bioreactors compared to the fuel from the K6 bioreactor and the pile are statistically significant in terms of moisture content, $\mathrm{pH}$, calorific value and ash content (Table 5).

Variance analysis results for the energetic properties of alternative fuel

Table 5

\begin{tabular}{|c|c|}
\hline Parameter & F factor value (collection point) \\
\hline Moisture content & $26.2^{*}$ \\
\hline $\mathrm{pH}$ & $64.0^{*}$ \\
\hline Heat incineration & 0.9 \\
\hline Calorific value & $12.7^{*}$ \\
\hline Ash content & $0.42^{*}$ \\
\hline
\end{tabular}

*values are significant with $p<0.05$

Aeration was used during the biodrying process in bioreactors $\mathrm{K} 4$ and $\mathrm{K} 5$, resulting in the moisture contents of the fuel decreased to the level of $18.7 \%(\mathrm{~K} 4)$ and $21.5 \%(\mathrm{~K} 5)$. The content of water in the fuel was reduced by $39 \%$ in the K4 bioreactor and $30 \%$ in the K5 bioreactor. The calorific values of the fuel in bioreactors K4 and K5 increased by 3.1 and $2.7 \mathrm{MJ} \cdot \mathrm{kg}^{-1}$, respectively. Similar effects (in terms of weight loss, moisture content and increase in calorific value) were achieved in the work of Colomer-Mendoza et al. [44], Ma et al. [45], Tom et al. [6] and Mohammed et al. [46]. The lack of aeration in the K6 bioreactor resulted in a reduction in fuel quality. Velis et al. [31] mentions that in the process of biological drying of municipal waste for the period of 7-15 days, the moisture content should decrease by at least 20\%. Bilgin and Tulun [16] conclude that 
during a 13-day of drying mixed municipal solid waste, it is possible to decrease the water content by over $30 \%$ with increasing the calorific value. Own research, in case of the K4 and K5 bioreactors, yielded even better results, which may be due to the type of dried material and the construction of the bed. No effluents appeared in bioreactors K4 and K5.

Temperature is an environmental variable with strong impact on the metabolism of microorganisms, population counts and species composition [47]. Temperatures below $20^{\circ} \mathrm{C}$ may result in slower or suspended biological waste processing [48]. Similarly, when the temperature exceeds $60^{\circ} \mathrm{C}$, the decrease in the activity of microorganisms can be observed alongside their selection [49]. MacGregor et al. [50] found the optimal temperature range for the biological processing of waste, during which the mineralisation of organic matter is maximised to be $52-60^{\circ} \mathrm{C}$. Liang et al. [51] found that the temperature of the stabilised material is the decisive parameter for process effectiveness. They also point out the second important factor in the stabilisation process, namely - moisture content. Liang et al. [51] conducted a study to find the interdependence between temperature, moisture content and microbiological activity. Based on the results, they concluded that the inhibiting effect of thermophilic conditions during waste processing may be rectified by increasing the availability of water in the substrate. Sundberg et al. [52] point out the synergistic effect of temperature and the $\mathrm{pH}$ reaction of the processed material on the efficiency of the process. Sundberg et al. [52] showed that in the temperature exceeding $46^{\circ} \mathrm{C}$ and with the $\mathrm{pH}$ below 6.5 , the degradation process of organic matter becomes slower. Similar results for decreased metabolic activity of microorganisms as a result of low $\mathrm{pH}$ were presented by Beck-Friis et al. [53]. Also Strom [54], based on his studies, concluded that the microorganisms show resistance to the alteration of one of the environmental factors, but not to the alteration of both of them simultaneously.

In this study, the tested factors which may have influenced the biodiversity of microorganisms were: temperature, moisture content and $\mathrm{pH}$. However, based on the measurements, no significant changes in the $\mathrm{pH}$ reaction of the alternative fuel were observed during the biodrying process $(\mathrm{pH} 7.46-8.25)$. The parameters with visible changes were: temperature $\left(24-76^{\circ} \mathrm{C}\right)$ and moisture $(16.2-39 \%)$. The regulation of the biodrying conditions visibly affected the number and biodiversity of the population of microorganisms found in the alternative fuel before and after the process. Own research shows a mixed population of microorganisms with different temperature, $\mathrm{pH}$ and moisture requirements at each of the stages of the process. Similar observations were made by Atlas and Bartha [55], who found diverse microorganism populations, e.g. mesophilic and preferring acidic habitats or thermophilic and intolerant of low $\mathrm{pH}$. Furthermore, Atlas and Bartha [55] point out that fungi are less susceptible to acidic $\mathrm{pH}$, compared to bacteria and more susceptible to temperatures exceeding $35-40^{\circ} \mathrm{C}$. The intensity of the airflow is yet another important factor affecting the number and species diversity of microorganisms found in the alternative fuel. It is a decisive factor for the temperature in the bioreactor during the biodrying process, which has a direct impact on the degree of biodegradation of organic matter and on the calorific value of the resulting fuel as well as its stability [11]. Based on the obtained results, it may be concluded that the use of aeration influenced the regulation of moisture content in the $\mathrm{K} 4$ and $\mathrm{K} 5$ bioreactors and affected the presence and number of the analysed groups of microorganisms as well as the increase in the calorific value of the fuel. 


\section{Conclusions}

1. The alternative fuel collected from the pile (before the biodrying process) was characterised by a much larger number and biodiversity of analysed microorganisms compared to the RDF from the containers after the completion of this process.

2. The moisture content in the alternative fuel produced from mixed municipal solid waste in the process of mechanical processing virtually excludes its use as an energy carrier. This means that biodrying is the appropriate process for further processing.

3. The process of biodrying in containers may lead to a satisfactory sanitation of the alternative fuel as well as to the decrease in its moisture content, leading to an increased calorific value of the fuel.

4. The regulation of the biodrying conditions visibly affected the number and species composition of the population of microorganisms found in the alternative fuel before and after the process.

5. Aeration in the system of maintaining a set temperature $\left(65^{\circ} \mathrm{C}\right.$ in this study) yielded similar results to the intensive aeration system.

6. Further research is needed to optimise the biodrying process for alternative fuel in order to increase its energetic and sanitary specifications.

\section{Acknowledgement}

The publication and research was financed by the Ministry of Science and Higher Education of the Republic of Poland - BM 4626/IIRiI/2014.

\section{References}

[1] Skutan S, Brunner H. Metals in RDF and other high calorific value fractions from mechanical treatment of MSW: Analysis and sampling errors. Waste Manage Res. 2012;30.7:645-655. DOI: $10.1177 / 0734242 X 12442740$.

[2] Malinowski M. Selected properties of an alternative fuel manufactured from municipal solid waste. Infrastruct Ecol Rural Areas. 2013;2013/4/2:125-139. http://www.infraeco.pl/pl/art/a_17260.htm?plik=1520.

[3] Mokrzycki E, Uliasz-Bocheńczyk A, Sarna M. Use of alternative fuels in the Polish cement industry. Appl Energy. 2003;74:101-111. DOI: 10.1016/S0306-2619(02)00136-8.

[4] Trezza MA, Scian AN. Waste fuels: their effect on Portland cement clinker. Cement and Concrete Res. 2005;35:438-444. DOI: 10.1016/j.cemconres.2004.05.045.

[5] Yuan J, Zhang D, Li Y, Chadwick D, Li G, Li Y, Du L. Effects of adding bulking agents on biostabilization and drying of municipal solid waste. Waste Manage. 2017;62:52-60. DOI: 10.1016/j.wasman.2017.02.027.

[6] Tom A, Pawels R, Haridas A. Biodrying process: A sustainable technology for treatment of municipal solid waste with high moisture content. Waste Manage. 2016;49:64-71. DOI: 10.1016/j.wasman.2016.01.004.

[7] Yasuhara A, Amano Y, Shibamoto T. Investigation of the self-heating and spontaneous ignition of refuse-derived fuel (RDF) during storage. Waste Manage. 2010;30:1161-1164. DOI: 10.1016/j.wasman.2009.11.003.

[8] Gao L, Hirano T. Process of accidental explosions at a refuse derived fuel storage. J Loss Prevent Proc. 2006;19:288-291. DOI: 10.1016/j.jlp.2005.05.016.

[9] Hogland W, Marques M. Physical, biological and chemical processes during storage and spontaneous combustion of waste fuel. Resour Conserv Recy. 2003;40:53-69. DOI: 10.1016/S0921-3449(03)00025-9.

[10] Hurka M, Malinowski M. Assessment of the use of EWA bioreactor in the process of bio-drying of undersize fraction manufactured from mixed municipal solid waste. Infrastruct Ecol Rural Areas. 2014;2014/IV/1:1127-1136. DOI: 10.14597/infraeco.2014.4.1.083.

[11] Adani F, Baido D, Calcatera E, Genevini P. The influence of biomass temperature on biostabilization-biodrying of municipal solid waste. Bioresour Technol. 2002;83/3:173-179. DOI: 10.1016/S0960-8524(01)00231-0.

[12] Sugni M, Calcatera E, Adani F. Biostabilization-biodrying of municipal solid waste by inverting air-flow. Bioresour Technol. 2005;96/12:1331-1337. DOI: 10.1016/j.biortech.2004.11.016. 
[13] Zeng Y, De Guardia A, Ziebal C, De Macedo FJ, Dabert P. Nitrification and microbiological evolution during aerobic treatment of municipal solid wastes. Bioresour Technol. 2012;110:144-152. DOI: 10.1016/j.biortech.2012.01.135.

[14] Passamani G, Ragazzi M, Torretta V. Potential SRF generation from a closed landfill in Northern Italy. Waste Manage. 2016;47:157-163. DOI: 10.1016/j.wasman.2015.07.024.

[15] Dębicka M, Żygadło M, Latosińska J. Investigations of bio-drying process of municipal solid waste. Ecol Chem Eng A. 2013;20(12):1461-1470. DOI: 10.2428/ecea.2013.20(12)132.

[16] Bilgin M, Tulun S. Biodrying for municipal solid waste: volume and weight reduction. Environ Technol. 2015:1-7. DOI: 10.1080/09593330.2015.1006262.

[17] Dziedzic K, Łapczyńska-Kordon B, Malinowski M, Niemiec M, Sikora J. Impact of aerobic biostabilization and biodrying process of municipal solid waste on minimization of waste deposited in landfills. Chem Process Eng-Inz. 2015;36/4:381-394. DOI: 10.1515/cpe-2015-0027.

[18] Montejo C, Tonini D, Marquez MC, Astrup TF. Mechanical-biological treatment: Performance and potentials. An LCA of 8 MBT plants including waste characterization. $J$ Environ Manage. 2013;128:661-673. DOI: 10.1016/j.jenvman.2013.05.063.

[19] Frączek K, Ropek D. Impact of the municipal landfill site on bacteria participating in transformation of soil nitrogen. Ecol Chem Eng A. 2011;18(5-6):685-695. http://tchie.uni.opole.pl/ece_a/ A_18_5-6/ECE_A_18(5-6).pdf.

[20] Frączek K, Ropek D. Municipal waste dumps as the microbiological threat to the natural environment. Ecol Chem Eng S. 2011;18/1:93-110. http://tchie.uni.opole.pl/ece_s/S18_1/S1_2011.pdf.

[21] Zeng Y, De Guardia A, Ziebal C, De Macedo FJ, Dabert P. Nitrogen dynamic and microbiological evaluation during aerobic treatment of digested sludge. Waste Biomas Valori. 2014;5/3:441-450. DOI: $10.1007 / \mathrm{s} 12649-013-9275-2$

[22] Sawamura H, Yamada M, Endo K, Soda S, Ishigaki T, Ike M. Characterization of microorganisms at different landfill depths using carbon-utilization patterns and 16S rRNA gene based T-RFLP. J Biosci Bioeng. 2010;109/2:130-137. DOI: 10.1016/j.jbiosc.2009.07.020.

[23] Giusti L. A review of waste management practices and their impact on human health. Waste Manage. 2009;29(8):2227-2239. DOI: 10.1016/j.wasman.2009.03.028.

[24] Yang K, Zhou XN, Yan WA, Hang DR, Steinmann P. Landfills in Jiangsu province, China, and potential threats for public health: Leachate appraisal and spatial analysis using geographic information system and remote sensing. Waste Manage. 2008;28(12):2750-2757. DOI: 10.1016/j.wasman.2008.01.021.

[25] Franke-Whittle IH, Confalonieri A, Insam H, Schlegelmilch M, Körner I. Changes in the microbial communities during co-composting of digestates. Waste Manage. 2014;34:632-641. DOI: 10.1016/j.wasman.2013.12.009.

[26] Sakka M, Kimura T, Sakka K. Comparison of microbial consortia in refuse-derived fuel (RDF) preparations between Japan and Germany. Biosci Biotechnol Biochem. 2006;70/12:2868-2873. DOI:10.1271/bbb.60261.

[27] PN Z 15006:1993: Odpady komunalne stałe -- Oznaczanie składu morfologicznego. (Municipal solid waste Determination of morphological contents). http://sklep.pkn.pl/pn-z-15006-1993p.html?options=cart.

[28] PN-EN 15407:2011: Refuse derived fuels. - Determination of carbon $(\mathrm{C})$, hydrogen $(\mathrm{H})$ and nitrogen $(\mathrm{N})$ content. https://sklep.pkn.pl/catalogsearch/result/?q=PN-EN\%2015407:2011.

[29] PN-G-04584:2001: Paliwa stałe -- Oznaczanie zawartości siarki całkowitej i popiołowej automatycznymi analizatorami (Solid fuels - Determination of total sulfur and ash through the automatic analyzers). https://sklep.pkn.pl/catalogsearch/result/?q=PN-G-04584:2001.

[30] Jakubowski M. Patent application No P121933. Dno napowietrzające kontenerowego urządzenia do obróbki, biosuszenia i kompostowania biofrakcji odpadów komunalnych (Aerating bottom of the container device for biological treatment (biological drying and composting) biofraction of municipal solid waste). 2013.

[31] Velis CA, Longhurst H, Drew R, Smith R, Pollard SJT. Biodrying for mechanical-biological treatment of wastes: A review of process science and engineering. Bioresour Technol. 2009;100(11):2747-2761. DOI: 10.1016/j.biortech.2008.12.026.

[32] Juniper. Mechanical-Biological Treatment: A Guide for Decision Makers, Processes, Policies and Markets. Juniper Consultancy Services. UK. 2005.

[33] Environment Agency. Eco-deco. http://www.environmentagency.gov.uk/wtd/679004/679026/679079/ 973452/?version=1\&lang=_e (accessed: 15.09.2007).

[34] Cozens P. EfW - an alternative vision. In: Papadimitriou EK, Stentiford EI, editors. Biodegradable and Residual Waste Management: First UK Conference and Exhibition. Harrogate, UK. 2004:464-472.

[35] European Committee for Standardization, 2006. Characterization of Waste - Sampling of Waste Materials Framework for the Preparation and Application of a Sampling Plan. EN 2006, 14899. http://www.srcosmos.gr/srcosmos/showpub.aspx?aa=14179. 
[36] PN-EN 18134-3:2015-11. Solid biofuels - Determination of moisture content - Oven dry method - Part 3: Moisture in general analysis sample. http://sklep.pkn.pl/pn-en-iso-18134-3-2015-11e.html.

[37] PN-ISO 1928:2002: Paliwa stałe -- Oznaczanie ciepła spalania metodą spalania w bombie kalorymetrycznej i obliczanie wartości opałowej. (Solid fuels - Determination of combustion heat by combustion in a bomb calorimeter and calculation of net calorific value). http://sklep.pkn.pl/pn-iso-1928-2002p.html?options=cart.

[38] PN-Z 15008-04:1993: Odpady komunalne stałe -- Badania właściwości paliwowych -- Oznaczanie ciepła spalania i obliczanie wartości opałowej. (Municipal solid waste - Testing of fuel - Determination of the heat of combustion and calculation of net calorific value). http://sklep.pkn.pl/ pn-z-15008-04-1993p.html?options=cart.

[39] PN-EN 18122:2016-01. Solid biofuels - Determination of ash content. http://sklep.pkn.pl/ pn-en-iso-18122-2016-01e.html.

[40] Giannis A, Makripodis G, Simantiraki F, Somara M, Gidarakos E. Monitoring operational and leachate characteristics of an aerobic simulated landfill bioreactor. Waste Manage. 2008;28:1346-1354. DOI: 10.1016/j.wasman.2007.06.024.

[41] Borglin SE, Hazen TC, Oldenburg CM. Comparison of aerobic and anaerobic biotreatment of municipal solid waste. J Air Waste Manage Assoc. 2004;54:815-822. DOI: 10.1080/10473289.2004.10470951.

[42] Paredes C, Roig A, Bernal MP, Sanchez-Monedero MA, Cegarra J. Evolution of organic matter and nitrogen during co-composting of olive mill wastewater with solid organic wastes. Biol Fertil Soils. 2000;32/3:222-227. DOI: 10.1007/s003740000239.

[43] Paoli L, Pirintsos SA, Kotzabasis K, Pisani T, Navakoudis E, Loppi S. Effects of ammonia from livestock farming on lichen photosynthesis. Environ Pollut. 2010;158/6:2258-2265. DOI: 10.1016/j.envpol.2010.02.008.

[44] Colomer-Mendoza FJ, Herrera-Prats L, Robles-Martínez F, Gallardo-Izquierdo A, Piña-Guzmán AB. Effect of airflow on biodrying of gardening wastes in reactors. J Environ Sci. 2013;25(5):865-872. DOI: 10.1016/S1001-0742(12)60123-5.

[45] Ma J, Zhang L, Li A. Energy-efficient co-biodrying of dewatered sludge and food waste: Synergistic enhancement and variables investigation. Waste Manage. 2016;56:411-422. DOI: 10.1016/j.wasman.2016.06.007.

[46] Mohammed M, Ozbay I, Durmusoglu E. Bio-drying of green waste with high moisture content. Process Saf Environ. 2017;111:420-427. DOI: 10.1016/j.psep.2017.08.002.

[47] Wolny-Koładka K, Żukowski W. Mixed municipal solid waste hygienisation for refuse-derived fuel production by ozonation in the novel configuration using fluidized bed and horizontal reactor. Waste Biomass Valor. 2017. DOI: 10.1007/s12649-017-0087-7. (in press).

[48] Mosher D, Anderson RK. Composting sewage sludge by high-rate suction aeration techniques - the process as conducted at Bangor, Maine, and some guidelines of general applicability. Interim Report Number SW-614d. US Government Printing Office. 1977.

[49] Voberková S, Vaverková MD, Burešová A, Adamcová D, Vršanská M, Kynický J, et al. Effect of inoculation with white-rot fungi and fungal consortium on the composting efficiency of municipal solid waste. Waste Manage. 2016;61:157-164. DOI:10.1016/j.wasman.2016.12.039.

[50] MacGregor ST, Miller FC, Psarianos KM, Finstein MS. Composting process control based on interaction between microbial heat output and temperature. Appl Environ Microbiol. 1981;41:1321-1330. https://www.ncbi.nlm.nih.gov/pmc/articles/PMC243918/pdf/aem00199-0043.pdf.

[51] Liang C, Das KC, Mc Clendon RW. The influence of temperature and moisture contents regimes on the aerobic microbial activity of a biosolids composting blend. Bioresour Technol. 2003;86:131-137. DOI: 10.1016/S0960-8524(02)00153-0.

[52] Sundberg C, Smars S, Jonsson H. Low $\mathrm{pH}$ as an inhibiting factor in the transition from mesophilic to thermophilic phase in composting. Bioresour Technol. 2004;95/2:145-150. DOI: 10.1016/j.biortech.2004.01.016.

[53] Beck-Friis B, Smars S, Jonsson H, Kirchmann H. Gaseous emissions of carbon dioxide, ammonia and nitrous oxide from organic household waste in a compost reactor under different temperature regimes. J Agr Eng Res. 2001;78(4):423-430. DOI: 10.1006/jaer.2000.0662.

[54] Strom PF. Effect of temperature on bacterial species diversity in thermophilic solid-waste composting. Appl Environ Microbiol. 1985;50/4:899-905. http://pubmedcentralcanada.ca/pmcc/articles/PMC291766/pdf/ aem00230-0168.pdf.

[55] Atlas RM, Bartha R. Microbial Ecology. Fundamentals and Applications. Menlo Park, California: Addison Wesley Longman; Chapter 8; 1998. 